\title{
Psychological Analysis and Education Countermeasures for College Students' Lack of Civilized Etiquette
}

\author{
Ling Li \\ College of life science, Hainan Normal University, Haikou Hainan, 571158, China
}

Keywords: College students, Civilized etiquette, Psychological, Education countermeasures.

\begin{abstract}
Highly cultured and steeped in propriety, treating people with courtesy should be the basic civilization accomplishment of young college students. The current state of civilized etiquette accomplishment of part of college students is worrying, while the comprehensive quality needs to be improved. This article analyzes the psychological factors of college students' lack of civilized etiquette in-depth and put forward the education countermeasures for improving the civilized etiquette accomplishment of college students.
\end{abstract}

\section{Psychological analysis on contemporary college students' lack of civilized etiquette}

\section{The influence of personality factors}

Psychological research shows that, psychological barriers including withdrawn, shy, timid and overcautious, inferiority will seriously affect the personal social contacts. ${ }^{[1]}$ Influenced by various factors, some college students show the characteristics of introversion, shy and inferiority. Introverted shy college students tend to be loners, not willing to greet "hello" when meeting teachers. They show people the impression of not polite. The self-abased college students tend to have too low self assessment, improperly belittle themselves and can't accept themselves. Serious self-abased college students even always feel others look down on themselves. They are afraid of interpersonal communication, hard to be civilized and polite.

With distinct contrast with college students have heavy inferiority complex, part of students are easy to show the characteristics of self-centeredness, self-approbation and conceited arrogance. They grew up in the center position of a family and have a self-centered thinking mode. They show characteristics of selfishness, narrow-minded. In the process of communicating with others, it is hard for them to show sincere respect for others. They are lack of the generosity of "don't do to others what you don't want others to do to you". They are self-centered, doing whatever they want to do as well as however they want to do. They are egoistic. Self-conceit is a kind of unrealistic psychology refers to people who is over confident with his/her own ability overestimated. Self-conceited college students show an attitude of having a swelled head with haughty arrogant speech and deportment, always looking down upon others, and even being insolent and rude to teachers and elders.

\section{The limitations of cognitive level}

Cognition refers to the process of people understanding things in outside world, including mental phenomena such as feeling, perception, memory and thinking. Cognition is the basis of emotion and will. Because of lack of rational cognition on civilized etiquette, college students have emotional disorders and behavioral disorders.

The limitations of college students' cognition on etiquette can be seen most clearly in college students' general lack of awareness of the value of civilized etiquette and showing "no etiquette needed". Firstly, although China is always famous for "state of ceremonies", recent history, especially the New Culture Movement knocked down the traditional Confucian culture, also the cultural revolution basically interrupted the succession and development of traditional etiquette culture. Since China's reform and opening up, all educations, family education, school education, social education in our country haven't paid enough attention to effective etiquette education. This makes contemporary college students and even their parents ignore the value and significance of etiquette. Secondly, under the background of the age of reform and opening, multiple values and cultural thoughts in the west 
have a big impact to young people's spiritual world. The pursuit of freedom, personality and success has become the intrinsic value orientation of contemporary college students. Many students think that "Knowledge-learning" is the right way, while "etiquette--reaching" is not essential, "etiquette-reaching" does not belong to life necessities. College students of utilitarianism find it difficult to see the deep interests and benefits that civilized etiquette can bring individuals. For example, the universal phenomenon such as the lights of the classroom in colleges and universities keep on and fans keep rotate after the class reflects the college students' shortsighted knowledge and experience. Some students think to make great invents, it has no need to care about small formalities, what's worse, a person who follows the traditional civilized etiquette often because of his/her weakness in the social competition. They misinterpret the humility way of a gentleman as one of the upright and honest, incompetent generation. Distorted ideological understanding of civilized etiquette makes contemporary college students do not respect etiquette. Thirdly, with the rise of the network, quite a few college students are addicted in the virtual world of Internet, playing down the need of real social interaction. In the virtual world formed by the Internet, they persist their old ways and feel at ease, so they often don't have to follow the social etiquette customs. This makes students have increasing indifference on civilized etiquette.

Second performance of this cognitive limitations is in severe lack of common sense of civilized etiquette, shown as "don't understand etiquette". Etiquette refers to people's showing politeness and ceremony of mutual respect and friendly in interpersonal contact and social activities, the criterion which used by people to handle interpersonal relationships, constraint their behaviors so as to show respect to others in social life. ${ }^{[2]}$ Politeness("Li" in Chinese) refers to expressing respect for others, while ceremony("Yi" in Chinese) refers to the form to express respect. Li and Yi are the unity of opposites, having correlation dependence. Ideological and moral education of our country has long attached great importance to the theory infusion, while overlooking behavior. As a result, even the educated people know they should respect others, they don't know how. From the scene when college counselors were visiting the dormitory, most of the students just sat in a chair, lied in the bed, indifferent and perplexed, specially and typically reflects college students' not understanding of etiquette. Even the college students respect teachers and students in their hearts, because of lack of learning and understanding of etiquette, they always show a lack of respect and upbringing.

\section{The influence of negative emotions}

College students go from "etiquette not needed" "don't understand etiquette" to "don't love etiquette". Some college students turn up their nose at traditional civilized etiquette, viewing them as the worn-out shoes; They are tired of prescriptive rules, do whatever they want; They hate well-behaved, red taped social life; They like negative way of life, taking wild oats, doing as one wishes, being as one is, making no attempt to make progress, personal independence of conduct as their personalities. College students don't love etiquette are always untidy on appearance, with dormitory bed out of order, smoking and drinking, being coarse and vulgar in speech.

\section{The influence of weak will}

College students' "don't love etiquette" is further developed into "don't obey etiquette". On the one hand, bad habits formed in the growing process is entrenched, difficult to be corrected; On the other hand, affected by the negative factors in the environment, new bad behaviors increase. The former such as spitting, throwing rubbish randomly. The latter such as uncivilized behaviors on the internet, smoking and drinking etc. Even though some students want to change their impolite behaviors, they will also live in their old bad living habits and behaviors egoistically because of weak will. For example, some students have been reminded of don't wear slippers into the classroom again and again, but still wear slippers to the classroom. Some teachers remind students class to turn off the lights and fans, but once the class is over, students will break up a hubbub, keep themselves to themselves, lack of basic consciousness of civilized etiquette. 


\section{Education countermeasures for improving college students' civilized etiquette accomplishment}

\section{Strengthening college students' mental health education, improving college students' self-esteem and self-confidence}

Self-esteem and self-confidence are the psychological basis of civilized and polite. It should pay attention to and strengthen college students' mental health education, make them set up the independent consciousness of the development of mental health, have correct view of themselves and accept themselves through classroom teaching or counseling of Mental health education. Optimizing the psychological quality, paying attention to the cultivation of good conduct including self-respect, self-confidence, self-discipline, self-improvement; Helping college students to set up a positive attitude to communication and master the methods of interpersonal communication, learn to coordinate interpersonal relationship and enhance the ability of treating people with courtesy; Promoting college students to cultivate perseverance volitional quality consciously, positively and optimistically face difficult setbacks, constantly strive to become stronger. Guiding students to learn to reflect, revising and perfecting themselves and consciously raising their civilized etiquette accomplishment through improving college students' self-esteem, self-confidence.

\section{Setting etiquette courses to promote college students' etiquette knowledge level}

South Korea attaches great importance to college students' etiquette education with upbringing courses set in universities, basic content of which is determined by the ministry of education. Establishing compulsory courses, while universities can increase the elective courses according to their own school faculty research status and setting special education institutions responsible for opening these courses facing all departments of the whole university. ${ }^{[3]}$ Although the etiquette education is the foundation education which should be started from primary school, just look at the current education system in our country, colleges should waste no time in the increase of the course of etiquette education. The root cause of our country college students' lack of civilized etiquette is that students lack correct understanding of the civilized etiquette. The arrangement of etiquette education in various colleges and universities should be strengthened. Each college and university should open the compulsory course, public elective course of etiquette education combining the practical teachers of itself to make etiquette education step on a pathway of normalization and systematism. Besides, each college and university should arise the college students to attach great importance to the civilized etiquette and make college students understand daily life etiquette and the significance and importance of moral rules through etiquette course's systematic interpretation of the important value of civilized etiquette on individual development as well as the strategic importance of civilized etiquette on social progress. Just as Emily `Post, the editor of the world famous A collection of choice specimens of western etiquette, said: There are countless of disciplines on the surface of the etiquette, but the fundamental purpose of which is to make the world a place full of fun, make people become approachable. People should pay attention to the application type and skill property of the course teaching, avoid pure theoretical teaching in the classroom. Teaching through lively activities, teaching through actions. Enhancing the students' situation experience of civilized etiquette, conducting social practice of civilized etiquette in-depth, creating the accomplishment of civilized etiquette in practice. At the same time, carrying out the education policy of whole staff education, giving full play to "carrier effect" and "permeation effect" of teaching activities in all subjects. Adding etiquette education in the teaching of all subjects, especially the general education curriculum such as ideological and moral cultivation and basic law education, occupational career planning of college students, the psychological healthy education of college students etc., all should stipulate the etiquette goals of teaching to make college students' etiquette education productive.

\section{students \\ Creating good etiquette culture atmosphere, cultivating the etiquette emotion of college \\ College and universities should list etiquette education in the master plan of cultural quality} education as well as the general objective of construction of campus culture. Campus cultural activities have a strong educational function. In the process of strengthening the etiquette education, 
they should construct the campus culture with civilized etiquette as the theme strongly, training and stimulating the enthusiasm of college students' learning and practice of civilized etiquette. They should inspire students' enthusiasm to learn civilized etiquette around the main content of college students' image etiquette, social etiquette, public etiquette etc., by the help of traditional advertising platforms such as posters, publicity columns etc. and new medias such as group learning organization, Wechat etc. in the form of civilized etiquette initial written proposal, catch-phrase, apothegm, network discussion etc. They should actively create a good atmosphere of civilized etiquette, make students change their negative affections of etiquette and actively enter in learning and training of etiquette through the organization of CYL Day activities of civilized etiquette by Youth League branch in each class; Holding civilized etiquette knowledge contest, civilized etiquette special lecture; Conducting civilization star competitions, the creation activities of civilized dorm, classroom and network etc., Organizing students to attend training of communicative manners, teachers etiquette, profession etiquette, make-up costumes etc. As a recessive classroom, school environment has a subtle influence on students. Colleges and universities should create civilized and beautiful campus vigorously to give full play to the role of environment education. At the same time, pay attention to strengthen teachers' moral construction. The ancient people said: "If one were moral him/herself, no order needed to make one obey; if one were dishonest, although there were orders, no one would obey." Rich knowledge can make one a teacher, while exemplary conduct. The teacher is both the civilized etiquette educator as well as the observer. Being a model for others, creating a good civilization etiquette image of a teacher is the best education to students.

\section{Strengthening the supervision of the civilized etiquette to form etiquette habit of college students}

College students' etiquette habits is still not enough just by the cultivation of inner self-discipline. The civilized etiquette management supervision, evaluation and the follow-up education mechanism shall be established and improved. Commending college students who follow civilized etiquette and advocating everybody to learn. As for college students who don't follow civilized etiquette, counselors of each grade should carry out criticism education, set training links and carry out etiquette training to change the bad behavior habits of this part of the students. Setting reward and punishment measures to strengthen the positive effect of civilized etiquette, getting rid of the negative effects of uncivilized behaviors. As for the uncivilized behaviors they refuse to mend their ways after repeated education, setting lighthouse to have urge and warning effect on students' individual behaviors.

The construction of education websites take civilized etiquette as the theme to serve college students' etiquette education

College students' learning is autonomous, initiative and flexible. They are good at using new medias to get the required information and energy for their own growth and development. The civilized etiquette education base is built through new network medias. Here mainly refers to subject education websites or web pages integrate thoughts, knowledge, interests and service together should be constructed, dynamic lively network ideological and political education should be carried out actively to form online and offline resultant force of ideological and political education. At the same time, college students' rational and civilized surfing the Internet should be guided to avoid the form of behavioral habits such as phone freak, mobile phone overuse in the era of times.

\section{Carrying forward the Chinese traditional etiquette culture, improving college students' etiquette accomplishment}

Famous historian, Mr. Qian Mu once said:"The core of Chinese traditional culture is Li(politeness)." ${ }^{[4]}$ Not only the ancient Guanzi took propriety, justice, honesty and honor as four dimensions of the country, comrade Mao Zedong also took propriety, justice, honesty and honor as four dimensions of the country:"propriety, justice, honesty and honor, the four dimensions of a country; No carrying out of the four dimensions, the country would not be like a country!" The essence of $\mathrm{Li}$ (politeness) is the rules, the truth. Obeying $\mathrm{Li}$ can make people serious without transgressing what is right. The etiquette culture of the Chinese nation from generation to generation 
has cultivate Chinese moral sentiment a generation after generation, forming the concept of Chinese customs and regulating the Chinese people's speech and behavior. Although some of traditional etiquette culture content have been out of date, lagging behind the development of the modern civilization needs, the containing essence is still suitable for our age and must will be an effective weapon for the reconstruction of China harmonious socialist society. For example, in the aspect of family, respecting the old and cherishing the young, the father is affectionate and the son is dutiful, respecting for seniority, couple conjugal love, showing love and respect as good brothers should etc. could be stressed, "of all virtues filial piety is most important" "Harmony brings wealth" etc. could be advocated. In the aspect of the society, honesty and trustworthiness, mutual affection, with good intention toward others, helping sb. achieve success etc. could be stressed, while "don't do to others what you don't want others to do to you" "Being able to establish oneself, one should help others to do so, being able to reach one's goal, one should help others to do so"'"'is old I old as well as old person, is young I young as well as young people" etc. could be advocated. In the aspect of a country, the country and the nation's sense of honor, honest and upright official career, affectionate to the people as well as love the people could be stressed, while "the whole world as one community" "exercising government by means of virtue" "repaying the country with supreme loyalty" "everyone is responsible for his country" could be advocated. etc. In the aspect of nature, reverence of nature could be stressed, while "man is an integral part of nature" "people are my brothers and all things are my kinds" "the Tao way follows nature" etc. could be advocated. All these concepts have eternal values. They are timeless treasures of traditional culture as well as core ideas of traditional virtues. Therefore, to let students understand traditional etiquette knowledge, grasp basic requirements of traditional etiquette and practice traditional etiquette norms help to inherit and carry forward traditional etiquette culture essence and construct socialist advanced etiquette culture; making for improving college students' civilized etiquette accomplishment, showing contemporary college students' upbringing, grace, and charm.

\section{References}

[1] Psychological counseling, Wang Daozhi compiled. Beijing: China commercial press, 2002.

[2] Huang Ju Liang. University students etiquette culture, Shanghai, East China Normal University press, 2007.

[3] Piao Xuehua. China and South Korea college students' etiquette education comparison research, Yanbian University, 2010.

[4] Gui Shu Qin. University students traditional etiquette education exploration, School party construction and ideological education, 2010: 84-2010.

[5] Kalinin . Discussion on communism education, Chen Changhao translation. Beijing: Times publishing house, 1953. 